\author{
G.B. Madiyeva $^{1}$ iD, E. Hoffmann ${ }^{2}$ iD , A.T. Aliakbarova ${ }^{3}$ iD \\ ${ }^{1}$ Al-Farabi Kazakh National University, Kazakhstan, Almaty, \\ ${ }^{2}$ Vienna University of Business and Economics, Austria, Vienna, \\ ${ }^{3}$ Al-Farabi Kazakh National University, Kazakhstan, Almaty, \\ e-mail: gbmadiyeva.kz@gmail.com; Edgar.Hoffmann@wu.ac.at; aliakbarova2014@gmail.com

\section{LINGUISTIC ATTRIBUTION OF MODERN KAZAKH ANTHROPONYMS}

\begin{abstract}
This article offers the stratigraphic analysis of modern Kazakh personal names. The data necessary to complete this study was collected from the birth records at the Departments of Civil Status Registration Offices (Almaly, Alatau, Auezov, Bostandyk, Zhetisu, Medeu, Nauryzbai, Turksib regions) of Almaty city. More than five thousand personal names of newborns born in2010 are subjected to this analysis. Modern Kazakh personal names are classified according to ethno-linguistic groups and subgroups. The ethnolinguistic aspect of the research allowed to reveal features of formation and development of modern Kazakh anthroponymy. The results of the study indicate that the Kazakh people were able to preserve the historical memory of culture and develop national traditions of naming through historical periods. The results of the research indicate that the national code of culture is preserved in Kazakh naming system as a fact of historical memory, the national traditions of naming are maintained accordingly. However, it should be noted that currently Kazakh anthroponymy is developing in four directions. Firstly, the Turkic-Kazakh traditions of naming are preserved, which are fundamental in the development of Kazakh anthroponymy. Secondly, there is an increase of Arabic names, which is associated with the growth of religious sentiment in society. Thirdly, penetration of Russian and European traditions of naming into Kazakh naming system. Fourthly, the occurrence of a new trend of naming: the formation of double names through a hyphen, double names that are written separately or together.
\end{abstract} ponymy

Key words: onomastics, anthroponymics, personal names, ethnolinguistic aspect, Kazakh anthro-

\author{
Г.Б. Мәдиева ${ }^{1}$, Э. Хофффманн'르, А.Т. Әлиакбарова ${ }^{3}$ \\ 'Әл-Фараби атындағы Қазақ, ұлттық университеті, Қазақстан, Алматы қ., \\ ${ }^{2}$ Вена экономика және бизнес университеті, Австрия, Вена к., \\ ${ }^{3}$ Әл-Фараби атындағы Қазақ ұлттық университеті, Қазақстан, Алматы қ., \\ e-mail: gbmadiyeva.kz@gmail.com; Edgar.Hoffmann@wu.ac.at; aliakbarova2014@gmail.com
}

Қазіргі қазақ антропонимдерінің тікдік айрықша белгілері

Мақалада қазіргі қазақ кісі есімдеріне стратиграфиялық та^дау жасалады. Зерттеудің дереккөзіне Алматы қаласы (А^малы, Алатау, Әуезов, Бостандық, Жетісу, Медеу, Наурызбай, Түрксіб аудандары) Азаматтық хал актілерін тіркеу (АХАТ) бөлімлерінен алынған туу туралы акт жазбалары жатады. 2010 жылы туылған 5000-нан астам жас нәрестенің есімдеріне та^дау жасалды. Заманауи қазақ есімдері этнолингвистикалық топтарға және топшаларға бөліп қарастырылады. Зерттеудің этнолингвистикалық аспектісі қазақ антропонимиясының даму және қалыптасу ерекшеліктерін анықтауға мүмкіндік туғызды. Зерттеу нәтижесі көрсеткендей, сәбиге есім беруде ұлттық мәдени код тарихи естеліктер ретінде мәңгі сақталып, нәтижесінде есім қоюға қатысты ұлттық, дәстүр өз жалғасын табуда. Аегенмен, қазіргі таңда қазақ антропонимиясы төрт бағытта даму жолында екендігін атап өтуге болады. Біріншілен, есім беруде қазақ антропонимиясы дамуына негіз болған түркі-қазақ, дәстүрі сақталып отыр. Екіншілен, қоғамдағы Аіни көзқарастың өсуімен байланысты араб тіліндегі есімдердің артуы байқаяады. Үшіншіден, қазақ есімдері қорына орыс және еуропа тілдері есім беру дәстүрінің енуі. Төртіншіден, есім берудің жаңа үрдісі туындап отыр: екі есімнен бірігіп жасалып, дефис арқылы жазылатын есімдер, екі есімнен жасалып, бірге немесе бөлек жазылатын есімдер.

Түйін сөздер: ономастика, антропонимика, кісі есімі, этнолингвистикалық аспект, қазақ антропонимиясы. 


\author{
Г.Б. МаАиева', Э. Хоффманн루, А.Т. А^иакбарова ${ }^{3}$ \\ 'Казахский национальный университет им. аль-Фараби, Казахстан, г. А^маты, \\ ²Венский университет экономики и бизнеса, Австрия, г. Вена, \\ ${ }^{3}$ Казахский национальный университет им. аль-Фараби, Казахстан, г. А^маты, \\ e-mail: gbmadiyeva.kz@gmail.com; Edgar.Hoffmann@wu.ac.at; aliakbarova2014@gmail.com
}

Языковая атрибуция современной казахской антропонимии

\begin{abstract}
В настоящей статье представлен стратиграфический анализ современных казахских мичных имен. Источниками исслеАования послужили актовые записи отАелов регистрации актов гражАанского состояния (РАГС) города А^маты: А^малинского, А^атауского, Ауэзовского, Бостандыкского, Жетысуского, Медеуского, Наурызбайского, Турксибского районов. Антропонимы развиваются в соответствии с различными ситуациями в обществе, подвергаются изменению по значению, форме, структуре. Анализу подверглось более пяти тысяч имен новорожденных 2010 года. Современные казахские мичные имена классифицируются по этноязыковым группам и подгруппам. Этнолингвистический аспект исследования позволил выявить особенности формирования и становления современной казахской антропонимии. Результаты исследования показывают, что в казахском именнике сохраняется национальный код культуры как факт исторической памяти, следовательно, сохраняются национальные традиции имянаречения. Тем не менее, следует отметить, что в настоящее время казахская антропонимия развивается в четырех направлениях. Во-первых, сохраняются тюркско-казахские традиции имянаречения, которые являются основополагающими в развитии казахской антропонимии. Вовторых, наблюдается увеличение арабских имен, что связано с ростом религиозных настроений в обществе. В-третьих, проникновение в казахский именник русской и европейской традиций имянаречения. В-четвертых, возникла новая тенденция имятворчества: образование Авойных имен через десис, двойных имен, которые пишутся раздельно или слитно.
\end{abstract}

Ключевые слова: ономастика, антропонимика, мичное имя, этнолингвистический аспект, казахская антропонимия

'The name of a thing is its soul'
F.M. Cornford from Religion to Philosophy

\section{Introduction}

Naming system of any language is distinguished by their peculiar national characteristics. However, due tovarious cultural and historical events, anthroponyms of different linguistic cultures have affected and influenced on each other.

It is known that proper names are borrowed more often and more easily than appellatives by virtue of their lexical values. (Superanskaya A.V.\& et.al., 1986: 132).

According to Kazakh academician A. Kaidar, before the spread of Islam, in accordance with Old Turkic tradition, Kazakh tribes took personal names from Orkhon, Yenisei and Talas inscriptions(the most ancient writings on the surface of stones). In old days the following names asDala, Bukha, Tuman, Temir, Tuglyk, Kutlu, Toka, Buga, Togrul, Monke, Kaban, Alptekin, Ertolywere given to newbons. From the beginning of the IXth century Islam started to develop intensively in Turkic world, therewas a huge influence of Arabic tradition on Turkic personal names(Kaidar A., 2005: 56).

In another study, Kerimbaev studied proper nouns in Kazakh folklore and emphasized the impact of Eastern folklore and culture on anthroponyms in fairy tales. According to Kerimbaev, in Eastern fairy tales the following Eastern names as Eskendir, Rustem, Farhad, Shyryn, Seiful-Malik, Irangaiyp shah Gabbas, Atymtai, Nashavan, Suleimenare widely used. Arabic-Iranian (Persian) anthroponyms are also met in Kazakh epos and epic poems (Kerimbaev D., 2004: 27)

According to scientist K. M. Musaev in order to conduct systematic investigation of anthroponyms in Turkic languages, it is necessary to develop integrated classification of anthroponymic system. One of the basic realization principles is the classification of anthroponyms according to layers. While analyzing the Kazakh lexicon he considered the following layers on the basis of lexical nomination and word formative affixes (Musaev K., 1984: 206):

1) original Turkic layer

2) borrowed layer - reflection of the historical, cultural, social and economic contacts of the Kazakh people with neighboring nations (Turkic, Iranian, Slavic and etc.).

\section{Experiment}

This study aims at analyzingmodern Kazakh personal names on the basis of above mentioned 
classification. The data (birth records) collected from the Civil Status Registration Departments of Almaty city. All registered personal names are categorized and analyzed using T. Zhanuzakov's KazakhRussian dictionary of names "Esiminiz kim? Vashe Imya" (Vocabulary "What's your name?").

The data necessary for the analysis were categorized into seven main ethnolinguistic layers.

\section{Ancient Turkic personal names:}

Male names: Adai - youngling, in an extended sense means baby, child, infant; Alpamys - alp (hero, strongman) + mamysh (hero-knight); Edige - goodnatured, big-hearted; Darkhan (tarkhan) - plural form tarkhat, in ancient Turkic written monuments means fame, rank; Edil - the name of the river Volga; Ertis - this name is given to the baby born on the banks of the Irtysh river; Oraz - happiness, luck; Ruslan - in old Turkic arslan means lion; Syrym tolerance, persistence, forbearing;

Female names: Bayan (ancient Turkic, Mongolian) - strong, powerful, wealthy; Orazgul - oraz in old Turkic means happiness, luck, gul from Persian translated as flower, in other words flower of happiness; Sandugash (Sanduvach) - nightingale; Ruslana - female form of the male name Ruslan with ending "a".

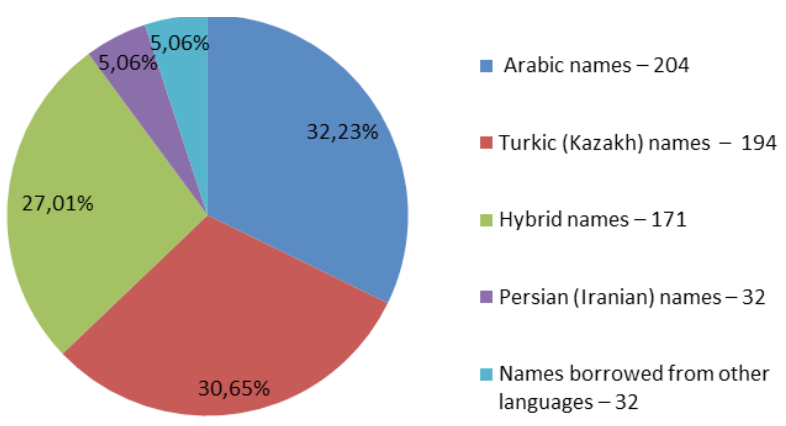

Diagram 1 - The percentage of native and borrowed Kazakh anthroponyms in 2010 (male names)

The percentage of native and borrowed names is indicated in diagram1.The number of male names given to newborns in 2010 was about 633 . The percentage of Kazakh (Turkic) names is about $30,65 \%$. The names of Arabic origin is around $32,23 \%$, whereas from Persian is $5,06 \%$. The rate of hybrids is $27 \%$. The rest of male names are borrowed from Hebrew, Germanic, Latin, Greek, Mongolian, Slavic, English, Spanish and Celtic.

The number of female names given to newborns in 2010 was about 482. The percentage of Kazakh
(Turkic) names is around $31,74 \%$. Names of Arabic origin comprises $26,52 \%$, whereas from Persian is 9,35\%. Hybrids in Kazakh naming system constituted $21,38 \%$. The rest of female names are borrowed from Hebrew, Latin, Greek, Mongolian, Slavic, English, Spanish and other languages.

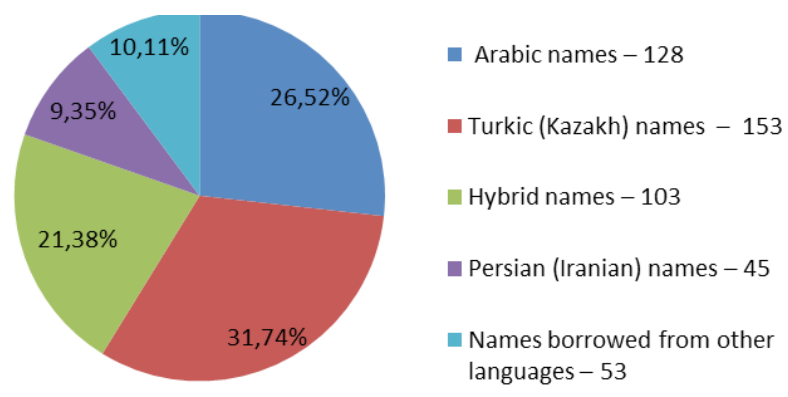

Diagram 2 - The percentage of native and borrowed Kazakh anthroponyms in 2010 (female names)

\section{Kazakh (Turkic) personal names:}

Male names: Abai - elder brother. But this meaning has the following options as: 1) writer $\mathrm{M}$. Auezov interprets Abai as "observant, forethoughtful, thinker"; 2) in Kazakh Soviet Encyclopaedia reveals the meaning of this name is explained as the real name of Abai Kunanbayev - Ibragim. Abai is a diminutive form of the name given by his mother" older brother; Aibar - magnifical, high-spirited, courageous; Ansagan - waiting, longing for the child; Bauyrzhan - bauyr in Kazakh means blood relative, zhan in Persian is interpreted as soul, in general associated with the meaning as philanthropic; Eldar - patriot who loves hisMotherland, nation; Erasyl - real hero; Erlan - growing up brave; Zangar - huge, high, magnificent;

Female names: Azhar - beautiful appearance, pretty face,; Akzhan - honest, impeccable; Ademibeautiful, lovely, gorgeous; Nurai - nur + ai (moonlight), in Arabic nur means ray of light, in Kazakh ai translated as moon; Saule - gleam, shine; Symbat - gracefulness, elegance, loftiness; Togzhan - affluent, substancial; Shattyk - merriment, joy;

Most of the widely spread Arabic personal names were of appellatives. The representatives of the ruling class in society used Arabic titles, ranks in addition to their personal names in order to show their nobility. For instance: Baraksultan, Kunanbai kazhy. These titles sometimes were given as names to children of the ruling class. For instance: Sultan, Amir, Malik and etc. (Ondasynov, 2011: 5-7). 
Agabekova examined personal names borrowed from Arabic, divided them into thematic groups taking into regard their historical-ethnographic significance.She emphasized the personal names as the most beloved names to Allah and the names of Prophets: Abdirahman, Abdirashit, Abduali, Abdirahim, Abdimalik, Abdizhappar, Abdikappar, Allaberdi, Zhapparkul, Rahmankul, Muhammed, Ahmet, Isa, Musa, Ibrahim(Abraham), Zhusip (Joseph), Zhunis (John), Dauit (David), Ahmetzhan, Kulahmet and etc (Agabekova Zh, 2005: 4-7 ).

After accepting Islam Kazakh families took note of names from Kuran and Bibleconnected with holiness and shrine. Linguistic forms as "olla/ulla" Allah; "abd/abdi) - slaveare widely used in Arabic personal names (Smagulov, 2006: 7).

Telkozha Zhanuzakov noted that the impact of the Arabic language varied, it had not affected on all Turkic languages the same way. The number of Arabic names is greater in the Azerbaijan, Uzbek, Tatar languages than the Kazakh and Kyrgyz languages in Eastern regions. Because Islam penetrated first to the Turkic people living in Front and Central Asia and developed rapidly (Zhanuzakov T., 1971: 106).

\section{Personal names derived from Arabic:}

Male names: Abzal - respected, dearest, noble; Abylai - (abyl // abil) grandfather, father; Azamat -1) majesty, honour, nobility; 2) a real gentleman, 3) conscientious man; Bayazit - a name transferred from Abuyazid, Abuyazid is explained as Yazid's father, Yazid means superior; distinctive; Daulet 1) affluence, wealth, happiness; 2) state, empire; $D i$ yar - country, region, province; Medet - assistance, help, favor; Miras -inheritance, heritage, descendant; Rasul - messenger, representative, ambassador; Samat - permanent, constant, everlasting;

Female names: Asyl-1) basis, root, 2) original, authentic, genuine, 3) valuable, precious; Alima literate, erudate; Әмина - honest, reliable, honorable; Gaini - most demanded; Zhamal - beauty; Malika - empress, mistress, queen, 2) wife of a king, monarch; Umit - 1) hope, 2) wish, desire; Farida 1) pearl; 2) incomparable, infrequent, unique;

According to scholars' scientific research due to the spread of Islam in Kazakh land Arabic culture influenced on all areas of socio-cultural life. As a result Kazakh name stock extended with the help of thousands of words and personal names derived from Arabic.

Musabaev investigated linguistic-cultural contacts between nomadic Turkic tribes and Persian tribes that followed settled way of life. According to Musabaev the above mentioned contact lead to the penetration of loanwords into the Kazakh lexicon (Musabaev, 2004: 13).

\section{Personal names derived from Persian (Iranian)}

Male names: Azat - unrestricted, independent, freeman; Arman - desire, cherished dream, goal; Darmen - strength, power, energy; Didar - appearance, look, face, vision; Eskendir - transformed version of the name Alexander. All the peoples of Asia and Arabia called Alexander the great (Alexander of Macedon) as Eskendir; Zhandos - zhon (soul) + dos (friend), friend of all people; Zhangir - (zhahan + gir) patron of the world, conqueror of the world;

Female names: Anar - pomegranate; Bibigul bibi (mistress) + gul (flower), full-blossomed mistress; Gulzada - gul (flower) + zada < zade < zaidan (baby, child), pretty babygirl; Gulnaz - gul (flower) + noz (affected manners, primness, coquettishness; graceful, charming, beautiful as flower; Dariga exclamation expressing surprise, emotional feeling. Oh, beautiful, pretty, wonderful; Dariya sea,stream; Meruert - pearl, mother of pearl;

Tsydenbaev studied Mongolian personal names which were derived from the Manchu-Tungus languages. He states that the number of proper names borrowed from the Tungus-Manchu languages is not too much. For example, Saya (Tibetan, 'sa-ya', 'zau-a') - "million"; Mynbai (Tibetan 'vim-bum') "hundred thousand"; Tana (Manchu 'tana') "mother of pearl"; Kalden (Tibetan 'galden-dgalden') - "happy"; surname Dabaev (Tibetan 'dava-ilava') -"moon", Shoibek (Tibetan 'choi') - "king"; Beisebai (Manchu 'beiise-beise') - "the title of the Mongol knyaz"/; Turkebai (Manchu 'turke-turka') "mountain river"; Kuralai (Manchu 'guran', 'djeiran') - "goat" (Tsydenbaev, 1972: 498-524).

\section{Personal names derived from Mongolian:}

Male names: Altai - altan (gold) + tai-tag (mountain); Barlas - strongman, noble,brave man; Erden (Erdene) - precious thing, in other words 'dear hero'; Zhambyl - fortress;

Female name: Bayan - strong, powerful, wealthy.

According to Boranbaeva, personal names derived from foreign languages being at the disposal of the percipient language undergo more or less significant transformations in comparison with their previous appearance and linguistic status inherent in the source language(Boranbaeva, 1989: 26-33)

Mahpirov states that "anthroponyms as Muhammed, Ibrahim, Ishak, Nuhand others, these names are not originally Arabic, and in turn, borrowed from the Hebrew by Islam. The borrowed names were adapted on the Arabic language (for example: Abraham - Ibragim, Jesus - Isa, Isaac - 
Ishak, and etc.) and these forms were assimilated by the Turks, which gives reason to consider them as Arabic borrowings" (Mahpirov, 1979: 23-29). According to the scientist above mentioned anthroponyms are derived from Hebrew through Arabic.

Zakiryanov explained the reason of widely spread Western European in connection with the process of interrelated names given to family members. She investigated Bashkir names borrowed from foreign languages and gave examples of such name combinations as: Charles Darwinovich, Albina Rimovna, Florida Marselevna (Zakiryanov, 1970: 154-157).

\section{Results and Discussion}

Personal names borrowed from other foreign languages:

Male names: Arthur (Celtic) - strong, powerful; Denis (in GreekDionysus) - (God of wine, winemaking, grape cultivation, fertility); Dias (Spanish Diaz) - day, day time, this name was given in honor of Spanish communist leader, politician Jose Diaz; Ibragim (Hebrew) - transformed from the name Abraham; Iliyas(Hebrew) - power, strength;

Female names: Bella (Latin) - pretty, beautiful, gorgeous; Venera (Latin Venus) - God of love and beauty; Diana (Latin) - the name of the goddess of the hunt and the moon; Zhanna (Hebrew) - pigeon; Klara (Latin) - light faced, clear, bright; Tamara (Hebrew) -date palm; Elvira(Spanish) - protected; Emma (ancient German) - precious, affectionate, friendly; Elena (Greek) - sunshine, light;

According to Smagulov, the combination of lexical and morphological elements of two or more foreign languages appeared in any language is called hybrids or hybrid names (Smagulov, 2006: 7).

Musabaev studied the history and the periods transformation of personal names derived from Arabic and Persian into Kazakh. In his research he stated that derived words from Arabic and Persian came through the Tatar language in the west, the Uzbek and Tadjik languages in the east (Musabaev, 1959: 55).

Doszhanov considers the interrelation of Turkic and borrowed personal names as indication of unity (Doszhanov, 2001: 20).

Arabic-Kazakh hybrids

Male names: Akylbek-arab. akyl (intellgence) + kaz. bek (representative of feudal society); Asylkhan - arab. asyl (dearest, precious) + kaz. khan; Alikhan - arab. gali (highest, high-minded, great) + kaz. khan; Amirkhan - arab. amir (ruler, governor, decree) + kaz. khan; Imanzhol - arab. iman (religious faith, belief) + kaz. zhol (way); Nurzhigit - arab. nur (light) + kaz.zhigit (man, male); Nurtilek - arab. nur (light) + kaz. tilek (wish); Ualikhan - arab. uali (ruler, principal, relative) + kaz. khan;

Female names: Asylai - arab. asyl (dearest, precious) + kaz. ai (moon); Asylarai - arab. asyl (dearest, precious) + kaz. arai (dawn, sunrise); Nursulu - arab. nur (light) + kaz. sulu (beautiful, pretty); Nurhanym - arab. nur (light) + kaz. hanym (misress, madam); Nursezim - arab. nur (light) + kaz. sezim (feeling); Nurshuak - arab. nur (light) + kaz. shuak (beam);

Kazakh-Arabic hybrids

Male names: Aisultan - кaz. ai(moon) + arab. sultan (ruler of administrative and territorial districts in the Kazakh steppe), Akadil - каz. ak (white) + arab. adil (honest); Bekaidar - Kaz. bek (representative of feudal society) + arab. haidar (strong, powerful); Erdaulet - каz. er (man, male) + arab. daulet (affluence, wealth); Ermadi - кaz. er (man, male) + arab. madi (substantial, material); Ermuhammed каz. er (man) + arab. Mohammad; Kuanadil - каz. kuan (look forward, be glad) + arab. adil (honest); Khandiyar - каz. khan + arab. diyar (country, region, province);

Female names: Aizhamal - кaz. ai(moon) + arab. zhamal (beauty, prettiness, charm, attraction); Ainur - каz. ai (moon) + arab. nur (light); Akziya - каz. ak (white) + arab. ziya (glitter, shine, light);Balhadisha - каz. bal (honey) + arab. Hadisha (prematurelyborn); Zhasnur - каz. zhas (young) + arab. nur (light); Erkenur - кaz. erke (naughty, spoilt) + arab. nur (light);

Shaihulov studied Kazakh and Bashkir personal names derived from Arabic and Iranian. He states that the common name stock of the Kazakh and Bashkir peoples were increased by many ArabPersian names. Today they are perceived as Kazakh and Bashkir names. First of all, these are the names that by their phonetic and morphological features could easily be assimilated with local names: Dilbere(bashk.) - Dilbara(kaz.) - "sweetheart, beloved"; Para(bashk.) - Sara(kaz.) - «mistress, lady»; Ielile(bashk.) - Zhalila(kaz.) - "majestic, gorgeous"andso on"(Shaihulov, 1984: 88).

Rustemov in his research "Arab-Iranian borrowed words in the Kazakh language"contends that there are about $15 \%$ (percent) of Arab-Iranian loanwords in the Kazakh language word stock (Rustemov, 1963: 4)

\section{Arabic-Iranian hybrids}

Male names: Alizhan - arab. gali(highest, highminded, great) + iran. zhon (soul); Kasymzhan - arab. kasym (handsome, good-looking, gallant) 
+ iran. zhon (soul); Nurzhan - arab. nur (light) + iran. zhon (soul); Nurbolat - arab. nur (light) + iran. bolat (steel); Rakymzhan - arab. rakym (merciful, charitable) + iran. zhan (soul); Omirzhan - arab. omir (life) + iran. zhon (soul);

Female names: Aishabibi - arab. gaisha (cheerful, hedonistic) + iran. bibi (mistress); Akylzhan - arab. ahl (intelligence, mind) + iran. zhon (soul); Asylzere - arab. asyl (dearest, precious) + iran. zere < zer (gold); Nurzada - arab. nur (light) + iran. zada (baby, child); Nurbibi - arab. nur (light) + iran. bibi (mistress); Nurdana - arab. nur (light) + iran. dana (sagacious);

Iranian-Arabic hybrids

Male names: Armanali - iran. arman (dream) + arab. gali (highest, high-minded, great); Zhanasyl - zhon (soul) + arab. asyl (dearest, precious); Dosmuhammed - iran. dos (friend) + arab. Mohammad; Zhanaidar - iran. zhon (soul) + arab. haidar (strong, powerful);

Female names: Zhannur - iran. zhon (soul) + arab. nur (light); Bibisharipa - iran. bibi (mistress)+ arab. tarip (noble minded, heavenly minded); Bibiaisha - iran.bibi (mistress) + arab. gaisha (cheerful, hedonistic); Gulnur - iran. gul (flower) + arab. nur (light);

\section{Iranian-Kazakh hybrids}

Male names: Zhanarys - iran. zhon(soul) + kaz. arys (formed from the name of the river Arys); Zhangeldi - iran. zhon (soul) + kaz. keldi (come into the world, see the light); Danabek iran. dana (sagacious) + кaz. bek (representative of feudal society); Doskhan - iran. dos (friend) + kaz. хан;

Female names: Gulaiym - iran. gul (flower) + kaz. aiym (my moon, my happiness, my beauty, like the moon); Zhansulu - iran. zhon (soul) + kaz. azhar (beautiful appearance, pretty face); Bibiazhar - iran. bibi (mistress) + kaz. azhar (beautiful appearance, pretty face); Bibikhan - iran. bibi(mistress) + kaz. khan;

\section{Kazakh-Iranian hybrids}

Male names: Aidos - kaz. ai (moon) + iran. dos (friend); Bekmyrza - kaz. bek (representative of feudal society) + iran. myrza (ruler, a man who has power over those who depend on him); Bekzat - kaz. bek (representative of feudal society) + iran. zada $<$ zade < zaidan (baby, child); Bekzhan - kaz. bek (representative of feudal society) + iran. zhan (soul); Elzhan - kaz. el (country) + iran.zhon (soul); Eldos - kaz. el (country) + iran. dos (friend);

Female names: Aibibi - kaz. ai (moon) + iran. bibi (mistress); Aizada - kaz. ai (moon) + iran. zada $<$ zade < zaidan (baby, child); Aidana - kaz. ai (moon)
+ iran. dana (sagacious); Aizhan - kaz. ai(moon) + iran. zhon (soul); Aizere - kaz. ai (moon) + iran. zere < zer (gold); Akzer - kaz. ak (white) + iran. zer (gold); Bekzada - kaz. bek (representative of feudal society) + iran. zada $<$ zade $<$ zaidan (baby, child);

\section{Arabic-Hebrew hybrids}

Male names: Imanzhusip - arab. iman (religious faith, belief) + heb. Joseph; Sultansuleimen - arab. sultan (ruler of administrative and territorial districts in the Kazakh steppe) + heb. Solomon; Nursuleimen - arab. nur (light) + heb. Solomon;

Interestingly, while analyzing the data, there were not Arabic-Hebrew hybrids among female personal names.

Professor Zhanuzakov states that before October Revolution the number of anthroponyms derived from Russian was not so much. According to Zhanuzakov, personal names, geographical names borrowed from Russian into Kazakhin historical sources and in spoken language were penetrated in the XVII-XVIII centuries. At that time Russian personal names were in small quantity, for example, Andre from Andrew, Mechael from Michael, Matbifrom Matthew, Mariamfrom Mary, Anna, Zhagor from Egor and so on (Zhanuzakov T., 1976: 41-44).

Personal names which can characterize social changes taken place in Kazakh society after October Revolution is called as neologisms by Zhanuzakov (Zhanuzakov T., 1982: 26).

\section{Personal names derived from Russian}

Male names: Zamir (for peace) - for the sake of peace in the world; Marlen - this name is a combination of the first syllables of the following surnames as Marks and Lenin, Renat - combination of abbreviated Russian words as Revolution, Nauka (science), Trud (labour);

Female names: Damira- da zdravstvuet mir (long live the world); Mira - mir (peace, peaceful life); Roza - personal name created from the name of the flower "rose".

\section{Modern Kazakh names:}

Male names: Armil, Adzhen, Ratmir, Samit (Summit), Samitkhan (Summit + khan);

Female names: Aidina, Ainel, Aisel, Dinel, Diya, Aruna, Ayana, Gulfar, Darina, Darisha, Ranya, Ramina, Sandina, Sarina;

\section{Conclusion}

The naming of persons is an integral part of the language picture of the world, moreover, anthroponyms directly reflect the historical course of socio-cultural events.Thereby, anthroponyms as 
a model of interaction of cultures are considered to be invaluable historical sources. Intercultural communicationscontribute to enrich anthroponymic fund of each nation. The study of ethnolinguistic aspects of anthroponyms allows to provide insight into the main stages of the historical development of the targeted people.

The results of study lead to the conclusion that modern Kazakh anthroponymy is developing in three directions:
- first of all,the Turkic-Kazakh tradition of naming which is fundamental in the development of the anthroponymic system continues toevolve being filled with new personal names.

- secondly, the eastern tradition that came into the Kazakh national space with the adoption of Islam, is developing intensively.

-thirdly, in recent years Russian and European traditions have been penetrated into Kazakh national traditions of naming.

\section{References}

Agabekova Zh. A. (2005). Kazakh tilindegi arab tekti kisi attarynyn takyryptyk toptary [Thematic groups of personal names in Kazakh]. KazNU Herald. Phil. series. № 6(88). Almaty, 4-7 pp. (in Kazakh)

Boranbaeva D.K. (1989). Lichnye imena zapodnoevropeiskogo proishozhdeniya u kazakhov, motivy ih vybora i praktika funktcionirovaniya $v$ rechi [Personal names of Western European origin in the Kazakh language, the motives of their choice and the practice of functioning in speech].Problems of onomastics and semasiology. Collection of proceedings. Alma-Ata: KazNU, p. 129. (in Russian)

Dzhanuzakov T.Dzh. (1976). Osnovnye problemy onomastiki kazakhskogo yazyka [Main issues of onomastics in the Kazakh language]. Abstract of doc. diss. of phil.sci. Alma-Ata. 129 p. (in Russian)

Doszhanov B.A. (2001). Kazakh tilindegi kone tulgaly antroponimder [Ancient anthroponyms in the Kazakh language]. cand. diss. of phil.sci. Astana. 148 p. (in Kazakh)

Zakiryanov K.Z. (1970). Lichnye imena u bashkir, i voznikshie v sovetskoe vremya. Lichnye

imena v proshlom, nastoyashem, budushem [Bashkir personal names appeared in Soviet times. Personal names in the past, at present and in future]. Moscow. 154-157 pp. (in Russian)

Kerimbaev D.M. (2004). Kazakh folkloryndagy zhalky esimderdin kuramy men etnolingvistikalyk sipaty [Ethnolinguistic characteristics and composition of personal names in Kazakh folklore]. cand. diss. of phil.sci. Almaty. 122 p.(in Kazakh)

Kaidar A.T. (2005). Abaidan "Shygaiga" deingi zhumbak esimder (Sectet names from Abai to Shygai). Tiltanym. № 1.56 p. (in Kazakh)

Mahpirov V.U. (1979). Antroponimy v "Divani lugat at-turk" i "Kudatgu bilik" [Anthroponyms in"Divani lugat at-turk and Kudatgu bilik"]. Soviet Turkology. №4. 23-29 pp. (in Russian)

Musabaev K. (2004). Turksko-iranskie kulturno-yazykovye kontakty [Turkic-Iranian cultural-linguistic contacts]. Turkology. №5 (13). 10-22 pp. (in Russian)

MusaevK.M. (1984). Leksikologiya turkskih yazykov [Lexicology of Turkic languages]. M.: Nauka. (in Russian)

Ondasynov N.D. (2011). Arab tekti Kazakh esimderi [Kazakh names of Arabic origin]. Almaty: Bilim. 224 p. (in Kazakh)

Rustemov L. (1963). Arabsko-iranskie zaimstvovaniya v kazakhskom yazyke [Arab-Iranian borrowings in the Kazakh].cand. diss. abstract. Alma-Ata. 20 p. (in Russian)

Smagulov A.(2006). Kazakh esimderi (Kazakh names). Encyclopedic reference. Almaty: Atamura. 432 p. (in Kazakh)

Superanskaya A.V., Staltmane V.E., Podolskaya N.V., Sultanov A.H.(1986). Teoriya Imetodika onomasticheskich issledovanii [Theory and methodology onomastic studies]. M.: Nauka. 366 p. (in Russian)

Tsydenbaev Ts. V. (1972). Buryatskie istoricheskie hroniki i rodoslovnye [Buryat historical chronicles and geneologics]. UlanUde, 1972. 498-524 pp. (in Russian)

Shaihulov A. (1984). Leksiko-semanticheskaya obshnost' bashkirskoi i kazakhskoi antroponimii [Lexico-semantic commonality of Bashkir and Kazakh anthroponyms]. Ethnic onomastics. M.: Nauka. 81-86 pp. (in Russian)

Zhanuzakov T. (1982). Ocherk kazakhkoi onomastiki. [Essay on Kazakh onomastics]. Alma-Ata: Nauka. 176 p. (in Russian)

Zhanuzakov T. (2008). Esiminiz kim? Vashe imja?[What is your name?]-Kazakh-Russian dictionary of names. Almaty: Ana tili. 176 p. (in Kazakh-Russian)

\section{Литература}

Ағабекова Ж. Қазақ тіліндегі араб кісі аттарының тақырыптық топтары // ҚазҰУ хабаршысы. Филология сериясы. Алматы, 2005. - № 6 (88). - 4-7 бб.

Боранбаева Д.К. Личные имена западноевропейского происхождения у казахов, мотивы их выбора и практика функционирования в речи // Пролемы ономастики и семасиологии. Сборник научных трудов. - Алма-Ата: изд. КазГУ, 1989. - C. 26-33.

Джанузаков Т.Дж. Основные проблемы ономастики казахского языка: Автореф. дис. ... док.филол. наук. -Досжанов Б.Ә. Қазақ тіліндегі көне тұлғалы антропонимдер. фил. ғыл. канд. ... дисс. - Астана, 2001. - 148 б.

Закирьянов К.З.Личные имена у башкир, возникшие в советское время. Личные имена в прошлом, настоящем, будущем. 
-Керимбаев Д.М. Қазақ фольклорындағы жалқы есімдердің құрамы мен этнолингвистикалық сипаты: филол. ғ. к. ... дис. -ҚайдарӘ.Т. «Абайдан «Шығайға» дейінгі жұмбақ есімдер» // Тілтаным. -Махпиров В.У. Древнетюркская ономастика (Имена собственные в «Дивану лугат-ит турк» Махмуда Кашгарского). - Алма-Ата: Гылым, 1990. - 159 с .

Мусабаев К. Тюркско-иранские культурно-языковые контакты // Түркология. - №5 (13). -Мусаев К.М. Лексикология тюркских языков. М.: Наука, 1984.

Оңдасынов Н.Д. Араб текті қазақ есімдері. - Алматы: Білім, 2011. - 224 б.

Рустемов Л. Арабско-иранские заимствования в казахском языке: Автореф. канд. дисс. - Алма-Ата, 1963. - 20 с.

Смағұлов А. Қазақ есімдері. Энциклопедиялық анықтамалық. - Алматы: Атамұра, 2006. - 432 б.

Суперанская А.В., Сталтмане В.Э., Подольская Н.В., Султанов А.Х. Теория и методика ономастических исследований. - Изд. 2-е. - М.: ЛКИ, 2007. - 256 с.

Цыдендамбаев Ц.Б. Бурятские исторические хроники и родословные. - Улан-Удэ, 1972. - С. 498-524.

Шайхулов А. Лексико-семантическая общность башкирской и казахской антропонимии // Этническая ономастика. - М.: Наука, 1984. - С. 81-86.

Жанузаков Т. Очерк казахской ономастики. - Алма-Ата: Наука, 1982. - 176 с.

Жанұзақов Т. Есіміңіз кім? Ваше имя? - Казахско-русский толковый словарь имен. - Алматы: «Ана тілі» баспасы ЖШС, 2008. - 176 б. 